\title{
Association between coal and firewood combustion and hospital admissions and mortality in Chile 2015 - An ecological approach
}

\author{
María Cristina Paredes ${ }^{1,2, A, C-F \oplus}$, María Pía Muñoz ${ }^{1, A, D-F \oplus}{ }^{\oplus}$, Macarena Valdés Salgado ${ }^{1,3, A-F \oplus}$, \\ Ana Karina Maldonado ${ }^{1, C-D, F} \odot$ \\ ${ }^{1}$ School of Public Health. Faculty of Medicine. University of Chile, Santiago, Chile \\ 2 Universidad Bernardo O'Higgins, Santiago, Chile \\ ${ }^{3}$ Center for Climate and Resilience Research, Santiago, Chile \\ A - Research concept and design, B - Collection and/or assembly of data, C - Data analysis and interpretation, \\ $D$ - Writing the article, E - Critical revision of the article, F - Final approval of article
}

\begin{abstract}
Paredes MC, Muñoz MP, Valdés Salgado M, Maldonado AK. Association between coal and firewood combustion and hospital admissions and mortality, Chile 2015- An ecological approach. Ann Agric Environ Med. 2020; 27(3): 418-426. doi: 10.26444/aaem/125010
\end{abstract}

\begin{abstract}
Introduction and objective. Burning coal and firewood generates toxic emissions that are associated with respiratory illness, cardiovascular disease, and even death. The aim of the study is to evaluate the association between county-level prevalence of household coal and firewood use and health outcomes, including total, respiratory, and cardiovascular mortality, as well as total and respiratory hospitalization rates.

Materials and method. The ecological study included data on the use of household coal and firewood in 139 counties obtained from the 2015 Chilean National Socio-economic Characterization Survey. Total, respiratory, and cardiovascular mortality, as well as total and respiratory hospitalization rates, were obtained from the Department of Health Statistics. Poisson models with robust error variance, Pearson linear correlation coefficients, and scatterplots were used to explore associations between household coal and firewood use and morbidity-mortality, stratifying by geographic zone.

Results. Total, respiratory, and cardiovascular mortality and total and respiratory hospitalization rates were 5.7 per 1,000, 552 per 100,000, 157 per 100,000, 92.5 per 1000, and 8.8 per 1000 inhabitants, respectively. The median prevalence of coal use for residential cooking, heating, or water heating was $3.64 \%$, while the median prevalence of firewood combustion was $12 \%$. In southern counties, age- and gender-adjusted respiratory mortality increased 2.02 (95\% Cl: 1.17-3.50), 1.5 (95\% Cl: 1.11-1.89), and 1.76-fold ( $95 \% \mathrm{Cl}: 1.19-2.60)$ for each percentage increase in household coal and firewood use for heating, cooking and heating water, respectively.

Conclusions. The prevalence of household coal and firewood used for heating and cooking was positively correlated with respiratory mortality and hospitalization in southern zone counties.
\end{abstract}

Key words

air pollution, biomass, mortality, hospitalization rate

\section{INTRODUCTION}

The United States Environmental Protection Agency (EPA) defines two types of energy: green or clean energy, which corresponds to renewable sources, including some forms of solar, wind, geothermal, biogas, and biomass power; and fossil fuels, including coal, natural gas, and petroleum [1]. The fossil fuel combustion is associated with negative consequences, such as environmental pollution and public health problems [2]. Burning firewood and coal releases carbon monoxide (CO), nitrogen dioxide $\left(\mathrm{NO}_{2}\right)$, sulfur dioxide $\left(\mathrm{SO}_{2}\right)$, and fine particulate matter $\left(\mathrm{PM}_{2.5}\right)$ into the environment, as well as organic compounds, such as benzene and polycyclic aromatic hydrocarbons (PAHs) [3]. These emissions produce negative health effects, especially among children and the elderly $[4,5]$.

In developing countries, many households burn firewood and/or vegetable coal (carbonized wood) for heating and cooking $[6,7]$. Socially-vulnerable families in these nations

Address for correspondence: Macarena Valdés Salgado, School of Public Health. Faculty of Medicine. University of Chile, 939 Av. Independencia, 8380453, Santiago, Chile

E-mail: macavaldes@ug.uchile.cl

Received: 06.03.2020; accepted: 04.07.2020; first published: 22.07.2020 tend to rely more heavily on these fuels than higher-income households and therefore suffer greater exposure to the pollutants derived from their combustion $[8,9]$.

In Chile, however, the use of clean energy, such as electricity and gas, is more strongly correlated with regional access and cultural factors rather than income level, as shown by the 2015 National Energy Survey and 2015 Chilean National Socio-economic Characterization Survey carried out by the Ministry of Social Development.

According to the national report about energy uses at home, the housing sector consumed about 50,763 GWh with a national average of consumption at home of about $8,083 \mathrm{kWh}$ per year; $39.6 \%$ of this consumption was obtained from firewood burning, followed by $31.4 \%$ of gas, and $25.7 \%$ of electricity. Taking into account the geographical length of Chile, the use of these fuels is related to the climatic characteristics; for instance, $99 \%$ and $76.7 \%$ of polluting emissions are attributable to housing firewood combustion in southern cities such as Coyhaique and Talca, respectively. On the other hand, in cities like Santiago, which is located in the central Metropolitan Region, only $38.5 \%$ of households burn firewood, and in northern cities like Arica, firewood burning use is almost $0 \%$ [10]. 
There are strategies focused on reducing pollution through firewood consumption, such as the banning of firewood burning in urban areas or the implementation of certified firewood, which is quietly more expensive than free wood. Considering, the climatic characteristics and the energy demands in the south of the country, these strategies could not be implemented properly, especially in socially-vulnerable households [11]. It should also be noted that the use of coal, a type of wood which is carbonized, is more dangerous for health and prevalent in the lowest social status households [12].

Air pollution has direct effects on public health: 3.5 million (95\% CI: 2.7-4.4 million) deaths and 4.5\% (95\% CI: 3.4-5.3) disability-adjusted life years (DALYs) worldwide in 2010 were attributable to residential air pollution (PAH) due to use of solid fuels [13]. Exposure to air polluted with fine particulate matter is associated with cardiovascular and respiratory diseases [14]. It has been hypothesized that this exposure triggers an inflammatory reaction on the alveolar level, resulting in a systemic reaction that promotes cytokine production, increases blood coagulation, and alters autonomic cardiac function [15]. Given that the air in many Chilean cities is highly polluted with particulate matter (PM) due to firewood combustion, especially in the southern zones, it is important to investigate the impact of these contaminants on the health burden of the country.

Short-term mortality is associated with PM exposure; each $10 \mu \mathrm{g} / \mathrm{m}^{3}$ increase in PM attributable to coal burning was associated with a $1.1 \%$ increase in daily mortality $(95 \% \mathrm{CI}$ : $0.3-2.0 \%$ ) in six US cities [16]. Time-series studies have shown that prolonged exposure to PM is associated with increased overall, cardiovascular, and respiratory mortality; Zhou et al. compared mortality patterns in two cities in the United States, and found that the PM composition determined a different pattern of health effect; indeed, the PM composition was an important aspect and showed that in cities like Detroit the secondary PM was associated with cardiovascular outcomes, instead of respiratory outcomes which were prevalent in cities like Seattle [17]. In Chile, a study by Barrios et al. carried out in Temuco - a city located in the southern region of the country, characterized by low temperatures and high consumption of woodburning and coal during the colder months - found an association between coarse particulate matter pollution and the number of medical visits for acute respiratory infections in children under 5 years of age [18]. A study by Cáceres et al. performed in La Pintana - a county located in the Metropolitan Region - found that the majority of households relying on polluting combustible fuels, such as coal or firewood, had levels of indoor air pollution inside the home that exceed recommended limits, with potentially deleterious health effects [19].

In recent years, developing energy policies that facilitate access to affordable and clean energy has become a greater priority in many countries worldwide. The United Nations Sustainable Development Goals and Chile's 'Energy 5050' initiative address the need to confront problems associated with energy poverty and air pollution $[20,21]$. To support such policies, it would be helpful to estimate local concentrationresponse functions (CRFs) at the population level - such as commune or county - to accurate the relationship between the prevalence of firewood and coal in households and the rate of health events. Therefore, the objective of this study was to evaluate the association between county-level prevalence of household coal and firewood use, and total, respiratory, and cardiovascular mortality, as well as total and respiratory hospitalizations.

\section{MATERIALS AND METHOD}

Population and study design. Continental Chile is located in South America and is $4,400 \mathrm{~km}$ in length. The country extends from a latitude of $17^{\circ}-56^{\circ} \mathrm{S}$ and a longitude of $66^{\circ}-75^{\circ} \mathrm{W}$. Administratively, the county is divided into 16 regions, which collectively contain 346 counties. Given the enormous length of the country and the diversity of its geographic characteristics, Chile has 9 types of climate, according to the Köppen-Geiger classification [22]: tundra (ET) $27.9 \%$, cold desert (BWk) 17\%, warm-summer Mediterranean (Csb) 16.3\%, cold semi-arid (BSk) $12.7 \%$, temperate oceanic (Cfb) 12.5\%, subpolar oceanic (Cfc) $7.2 \%$, cool-summer Mediterranean (Csc) 5.2\%, hot desert (BWh) $1.1 \%$, and polar (EF) $0.1 \%$. Therefore, the energy needs of the population are largely determined according to geographic zone of residence.

This ecological study examines age- and gender-adjusted total, respiratory and cardiovascular mortality, as well as total and respiratory hospitalization rates in Chile, and the relationship of these health outcomes with the percentage of households that use firewood and coal for cooking, heating, and water heating in 139 counties, using data from the 2015 Chilean National Socioeconomic Characterization Survey.

National Socio-economic Characterization Survey. The objective of the National Socio-economic Characterization Survey (CASEN) is to estimate income distribution and poverty indicators in Chile, serving as the main source of national data on poverty and social inequity [23]. The survey is carried out by the Ministry of Social Development every three years, and the fieldwork involves applying a questionnaire to each household selected. In 2015, the survey included modules on the education level, work activity, income, health status, and housing. The housing module included the following questions: What type of fuel or energy source do you typically use for cooking?; What type of fuel or energy source do you typically use for heating your home?; What type of fuel or energy source do you typically use for water heating? The possible responses were: gas (liquified or natural gas), kerosene or petroleum, firewood or firewood derivatives (pellets, chips, or briquettes), coal, electricity, solar energy, do not use any fuel, or do not have any type of heating system. The results from these questions were used to calculate the percentage of households that rely on coal and firewood for cooking, heating, and water heating in each county, as an indicator of residential fossil fuel use.

In addition, levels of multidimensional poverty were documented for each county to explore potential correlations between this variable and the health effects studied. The 2015, the CASEN survey addressed multidimensional poverty with items on education (school attendance, educational achievement gaps, and education level), health (malnutrition, health system coverage, and healthcare received), work and social security (occupation, social security benefits, and retirement benefits), housing and environment (habitability, basic services, and environment), and social networks and cohesion (social participation and support, equal treatment, safety) [23]. 
The data were stratified by geographic region in order to evaluate the effects of the various climates in Chile. To this end, the country was divided into three macro-zones: 1) Northern, corresponding to the near- and far-north regions Arica and Parinacota, Tarapacá, Antofagasta, Atacama, Coquimbo, and Valparaíso; 2) Central, corresponding to the Metropolitan Region, as well as the regions O'Higgins and del Maule; and 3) Southern, corresponding to the southern and far-south regions Biobío, La Araucanía, Los Ríos, Los Lagos, Aysén, and Magallanes and Antarctica.

Age- and gender-adjusted rates of health events. Data on hospitalizations and deaths for the year 2015 were obtained from Department of Health Statistics and Data (Spanish acronym DEIS) of the Chilean Ministry of Health, which is responsible for periodically collecting and publishing this type of information [24]. Data from the National Statistical Institute (Spanish acronym INE) for each county in the year 2015 was used to estimate the number of persons at risk for death in each group [25].

All-natural causes, respiratory (J00-J99), and cardiovascular (I00-I99) mortality rate, as well as, total, respiratory, and cardiovascular hospital admissions were studied, based on the ICD-10 code. To compare mortality rates, taking into account the age and gender demographic differences among 139 counties, the adjusted mortality rates were estimated using the direct method of standardization; the national demographic structure for the year 2015 was used as a reference.

Data analysis. Maps and tables were developed for descriptive analysis of the rates of each type of health event, as well as the prevalence of residential coal and firewood combustion by county.

To explore the association between the use of firewood and coal as the main sources of energy for cooking, household heating, or water heating at the county level and the health events, Poisson regression with robust variances was used to derive incidence rate ratios (IRRs) and 95\% CIs, stratifying by geographic zone. In this case, the logarithm of the agestandardized mortality rate was modeled using Poisson regressions. This allowed evaluation of the associations with wood-burning use at county-level [26]; this approach was preferred instead of modeling the expected number of death and adjusting by age and population due to the limited number of counties $(n=57)$. The robust variance approach was considered to take into account the overdispersion phenomenon.

The general model for each geographic zone (each zone included northern, central and southern cities, separately), including multidimensional poverty at county level was:

\section{Log (age and gender-adjusted mortality rate) $=\beta_{0}+\beta$ (\% use of firewood and coal at country level) $+\beta$ (\% use multidimensional poverty)}

For zones in which a statistically significant association was identified, Pearson linear correlation coefficients and scatterplots were used to complement the relationship between household coal and firewood use and morbiditymortality. Data analysis was performed using software Stata v14.0 and ArcGIS 10.1.

\section{RESULTS}

Total, respiratory, and cardiovascular mortality, as well as respiratory and circulatory hospitalization rates are shown in Table 1, and prevalence of coal and firewood as the main household fuel for cooking, household heating, and water heating are shown Table 2. The distribution of these events by county is shown in Figures 1 and 2.

Table 1. National-level health indicators, 2015

\begin{tabular}{lc}
\hline Total mortality rate, events per 1,000 inhabitants & 5.74 \\
\hline Respiratory mortality, events per 100,000 inhabitants & 55.2 \\
\hline Cardiovascular mortality, events per 100,000 inhabitants & 157 \\
\hline Total hospitalization rate, events per 1,000 inhabitants & 92.52 \\
\hline Respiratory hospitalization rate, events per 1,000 inhabitants & 8.76 \\
\hline
\end{tabular}

Table 2. Percentage of residential firewood and coal use and multidimensional poverty at county-level, CASEN 2015

\begin{tabular}{lcccccc}
\hline & $\mathrm{n}$ & Mean & Median & Min & Max \\
\hline Firewood/coal for cooking (\%) & 139 & 16 & 3 & 0 & 84 \\
\hline Firewood/coal for household heating (\%) & 139 & 52 & 64 & 0 & 100 \\
\hline Firewood/coal for water heating (\%) & 139 & 7 & 12 & 0 & 58 \\
\hline Multi-dimensional poverty (\%) & 139 & 23 & 22 & 5 & 58
\end{tabular}

The highest total mortality rate (unadjusted) was found in Independencia county (Central Zone), which is consistent with prior studies. It is likely that this figure is attributable to the high proportion of elderly residents living in Independencia, as well as the large numbers of hospitals and long-term care facilities located in this county [27]. The second- and thirdhighest total mortality rates were in Saavedra (Southern Zone) and Río Grande (Southern Zone), at 10 deaths per 1,000 inhabitants. In counties like General Lagos (Northern Zone), Primavera (Southern Zone), Río Verde (Southern Zone), San Gregorio (Southern Zone), Sierra Gorda (Northern Zone), and Timaukel (Southern Zone), total mortality for 2015 was 0 - no deaths were recorded during the year.

Los Muermos showed the highest prevalence of residential coal and firewood combustion for cooking, at $84 \%$ of households, as well as the highest prevalence of fossil fuel use for water heating, at $58 \%$. In Cochrane, $100 \%$ of households reported using coal and/or firewood for household heating. The counties Putre, Nueva Imperial, and Padre las Casas had the highest rates of multidimensional poverty at 58 , 46, 45\%, respectively; Providencia and Las Condes had the lowest rates $-5 \%$.

There were no consistent patterns in the correlations between multidimensional poverty and prevalence of firewood and coal use among the three zones. While multidimensional poverty was strongly correlated with coal and firewood combustion for all residential purposes in the southern zone - ranging from $50 \%$ for household heating to $68 \%$ for cooking - the relationship was weaker in the central zone $(<30 \%$ in all counties studied). In the northern zone, multidimensional poverty was correlated with the prevalence of residential coal and firewood combustion only for cooking (81\%) (Supplement).

However, multidimensional poverty showed strong correlation with the incidence of health events in the central zone: a positive correlation with total and respiratory mortality in the Central Zone (Fig. 3). The correlation with 


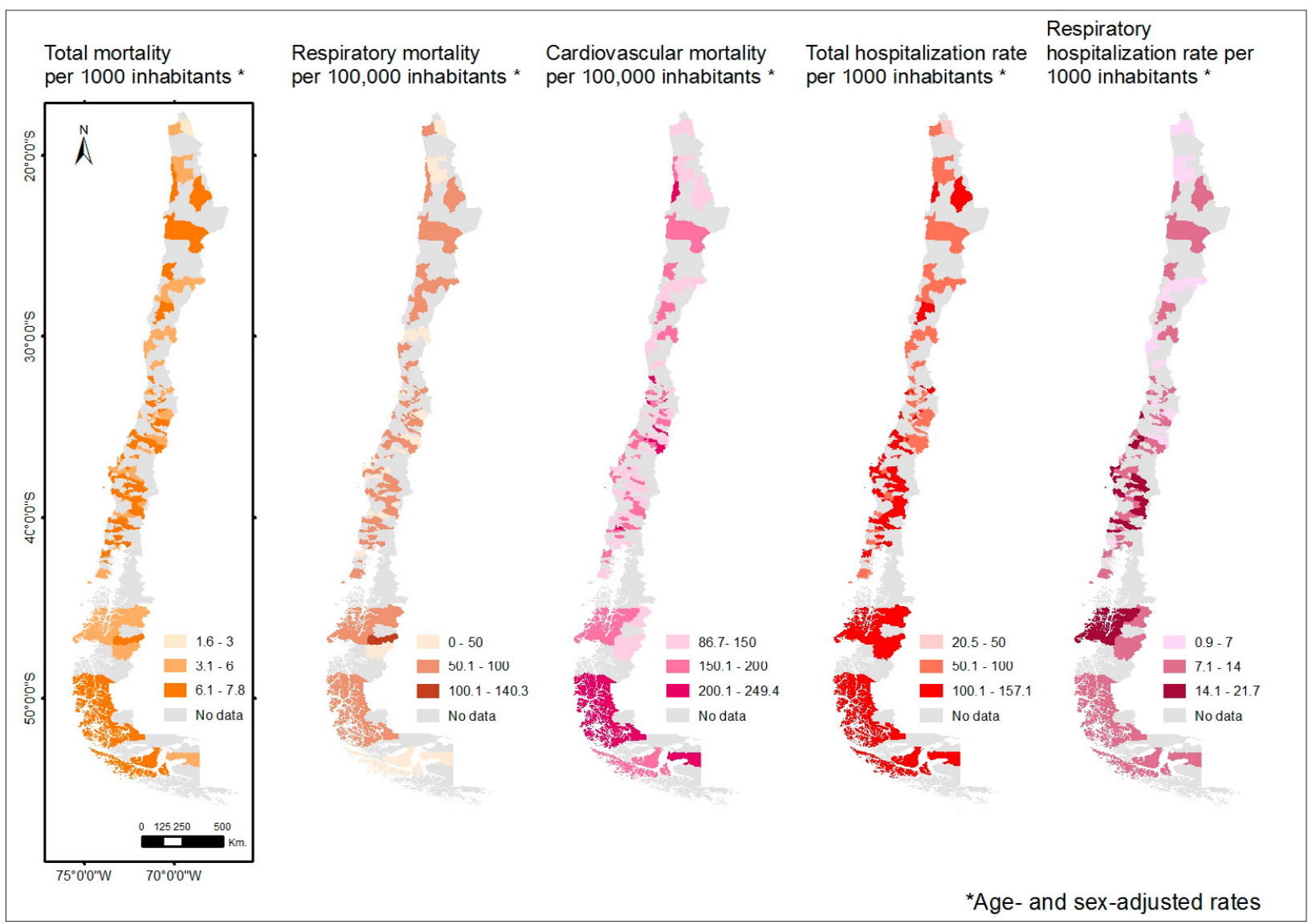

Figure 1. Health events by geographic zone, DEIS 2015

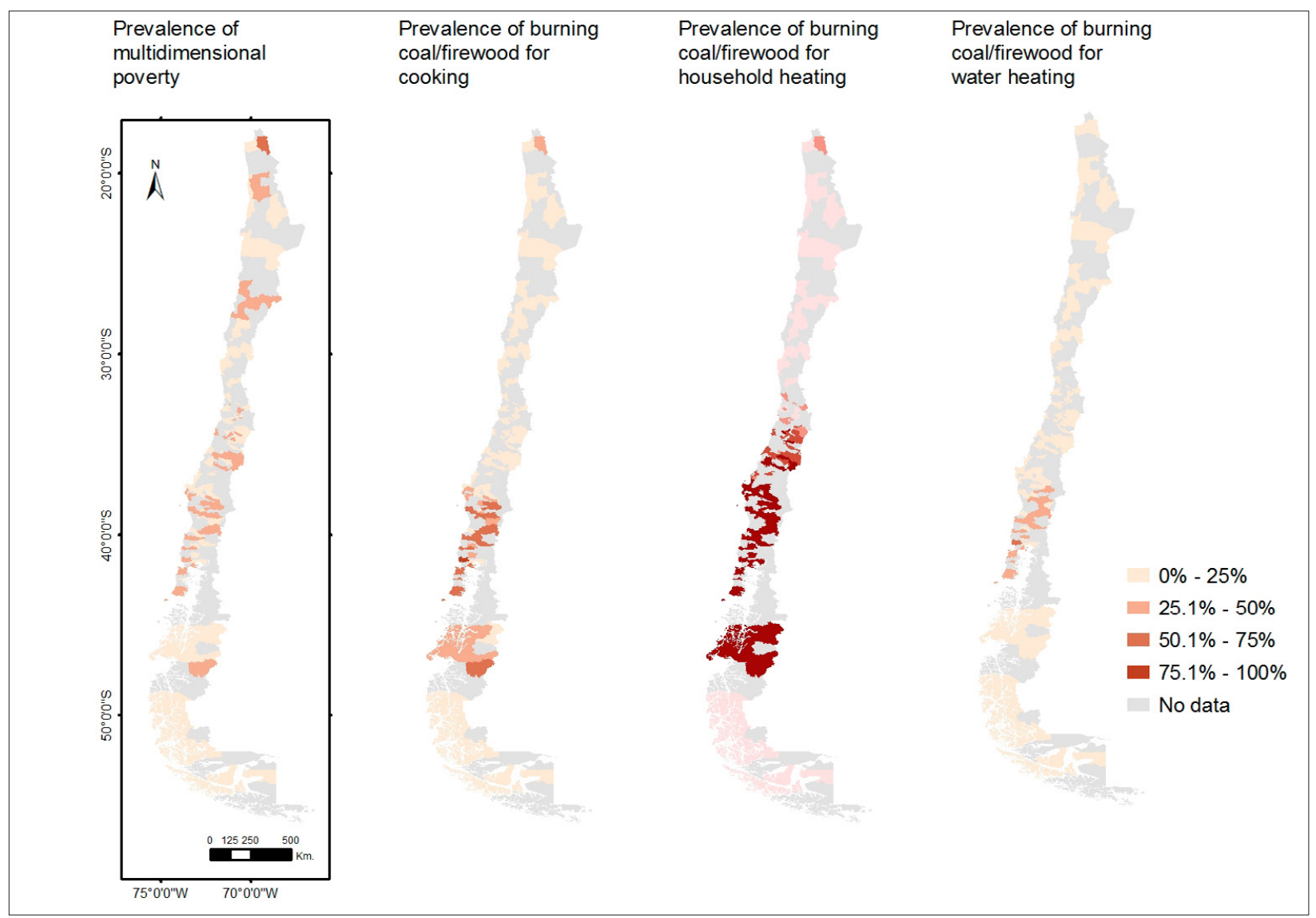

Figure 2. Prevalence (\%) of residential firewood and coal use for cooking, household heating, and water heating, CASEN 2015 

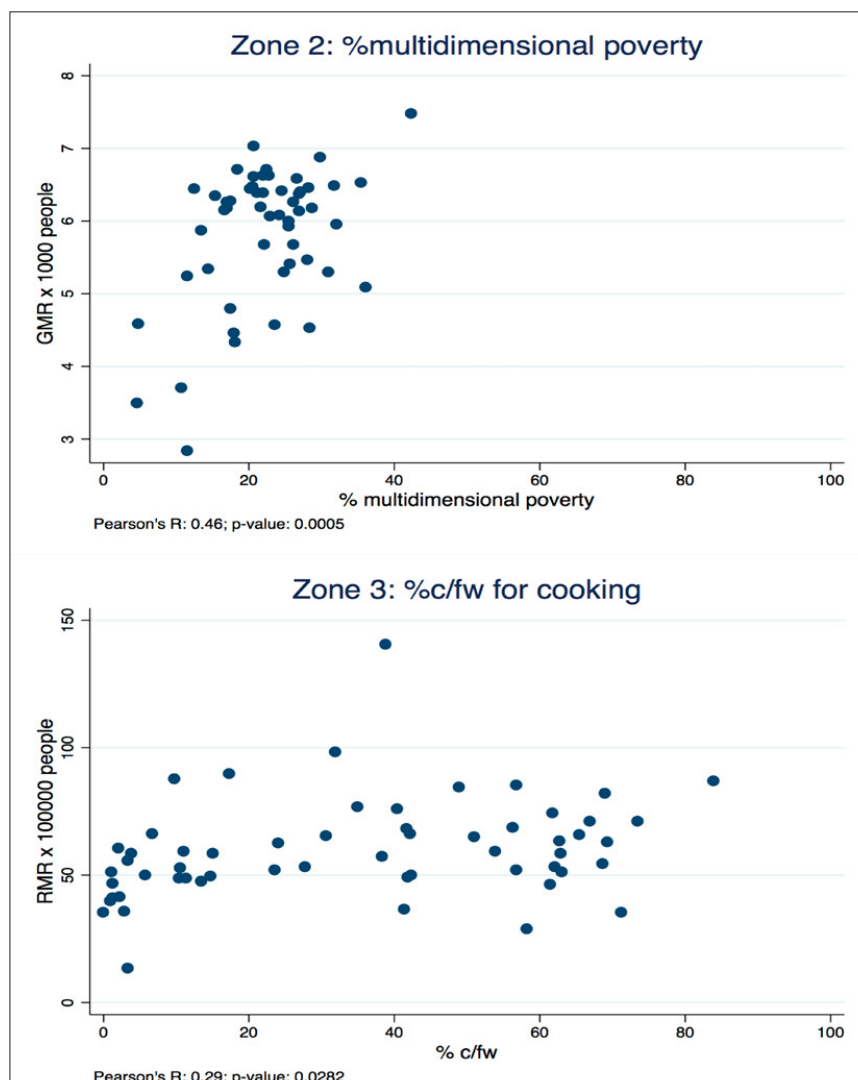

Pearson's R: 0.29 ; $p$-value: 0.0282
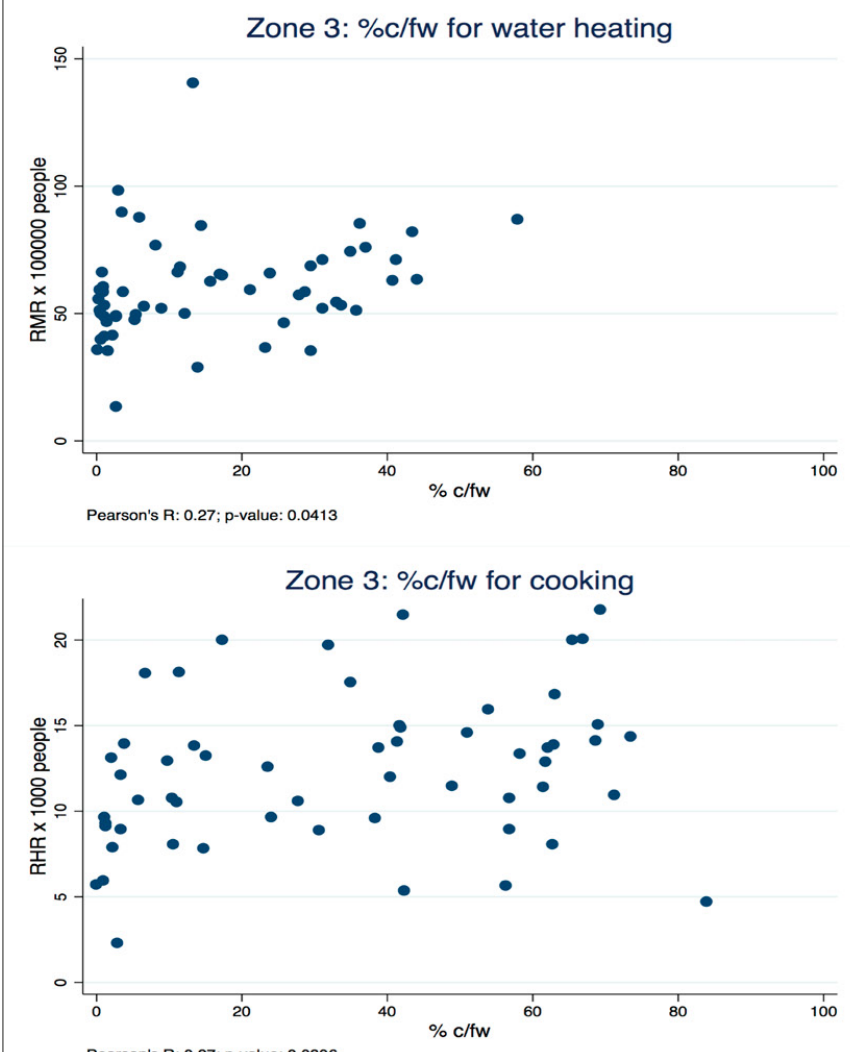

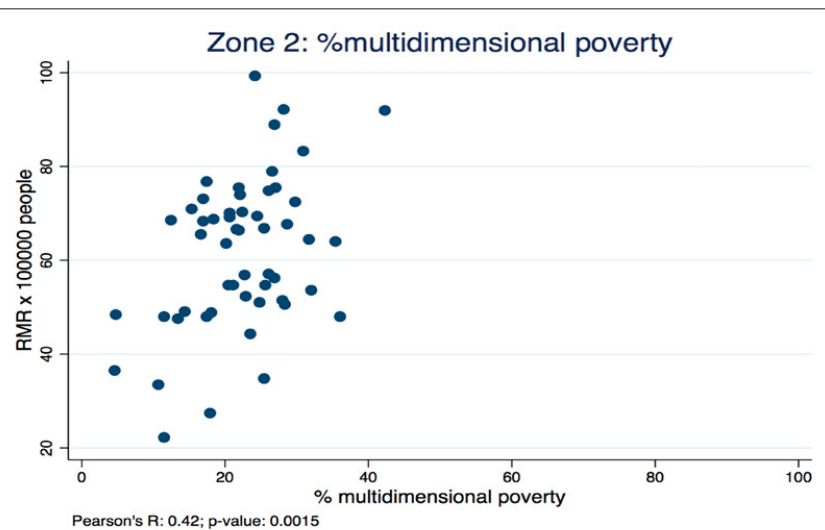

Zone 3: \%c/fw for household heating

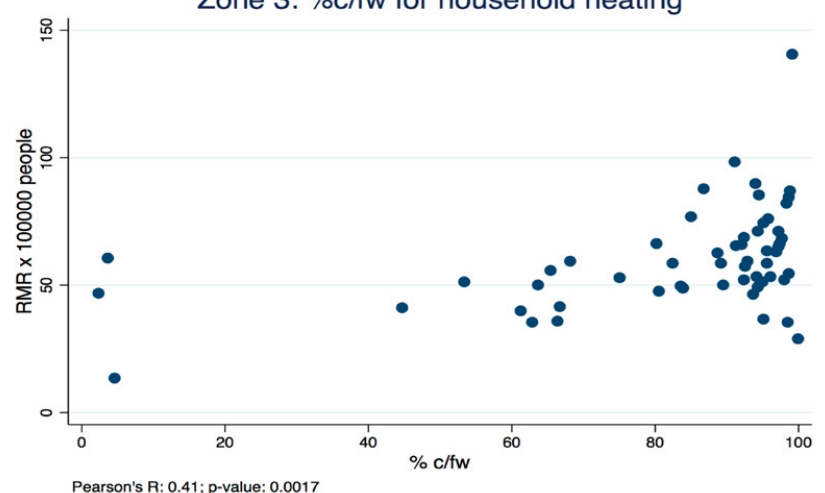

Zone 2: \%c/fw for cooking

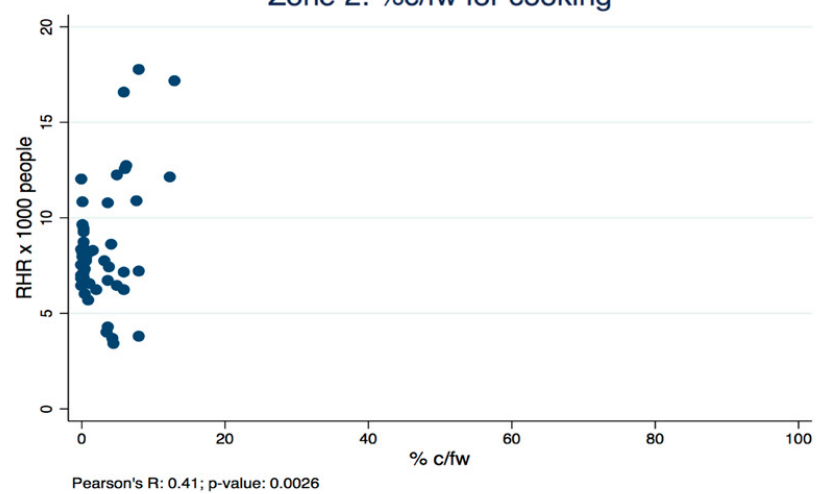

Zone 3: \%c/fw for household heating

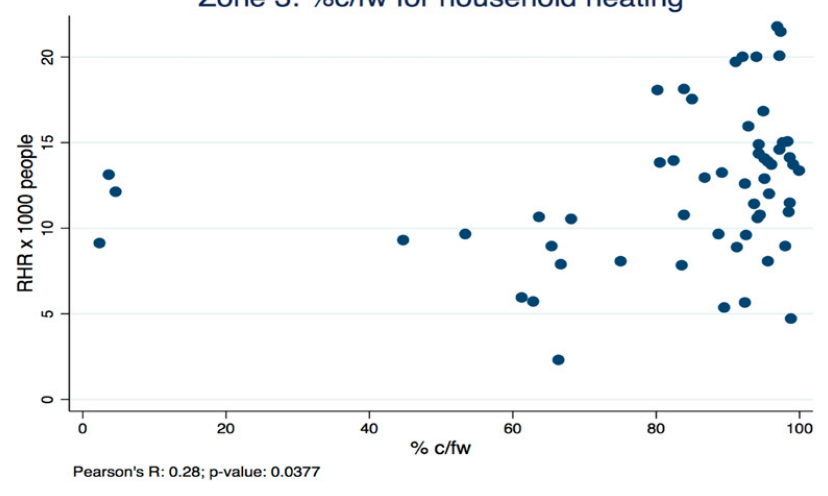

Figure 3. Prevalence of residential firewood and coal $(\% \mathrm{c} / \mathrm{fw})$ use for cooking, heating, and water heating and directly-correlated health events 
health events in counties of the southern zone was positive but not significant. A negative but not significant correlation between multidimensional poverty and health events were observed in counties of the northern zone; although it seemed surprising, the $\%$ multidimensional poverty was high in this zone and the variability of this measure was poor, then a pair of counties with high prevalence of poverty and low mortality rate caused this negative correlation (data not shown).

With the Poisson regression models (Tab. 3), the adjusted incidence rate ratio (IRR) for health outcomes were estimated for each firewood and coal use (cooking, household heating, and water heating). In counties of the central zone, the IRRs for firewood and coal for each propose, adjusted by multidimensional poverty, were not significant. In counties of the southern zone, each percentage increase in the prevalence of household firewood and coal combustion for cooking, household heating, and water heating was associated with a $1.5,2$, and a 1.8 -fold increase in respiratory mortality rate. Additionally, each percentage increase in the prevalence of household firewood and coal combustion for cooking and household heating was associated with a 1.5 and 2 -fold increase in the respiratory hospital admission rate.

Table 3. Poisson models adjusted by multidimensional poverty for $\%$ firewood and coal use at the county level, in cooking, household heating, and water heating in southern zone

\begin{tabular}{|c|c|c|c|c|c|c|}
\hline \multirow[b]{2}{*}{ RMR } & \multirow[b]{2}{*}{$\begin{array}{l}\% \text { of households that use firewood } \\
\text { and coal for cooking }\end{array}$} & \multirow{2}{*}{$\frac{n}{57}$} & \multirow{2}{*}{$\begin{array}{l}\text { IRR } \\
1.45\end{array}$} & \multicolumn{2}{|c|}{$95 \% \mathrm{Cl}$} & \multirow{2}{*}{$\frac{p \text {-value }}{0.005}$} \\
\hline & & & & 1.11 & 1.89 & \\
\hline & $\begin{array}{l}\% \text { of households that use firewood } \\
\text { and coal for household heating }\end{array}$ & 57 & 2.02 & 1.17 & 3.50 & 0.012 \\
\hline & $\begin{array}{l}\% \text { of households that use firewood } \\
\text { and coal for water heating }\end{array}$ & 57 & 1.76 & 1.19 & 2.60 & 0.004 \\
\hline \multirow[t]{2}{*}{ RHR } & $\begin{array}{l}\% \text { of households that use firewood } \\
\text { and coal for cooking }\end{array}$ & 57 & 1.46 & 1.00 & 2.14 & 0.050 \\
\hline & $\begin{array}{l}\% \text { of households that use firewood } \\
\text { and coal for household heating }\end{array}$ & 57 & 1.63 & 1.05 & 2.52 & 0.029 \\
\hline
\end{tabular}

RMR - Respiratory mortality rate; RHR - Respiratory hospital admissions rate.

Several counties in all three geographic zones showed counterintuitive, inverse correlations, such as lower rates of health events in association with a greater prevalence of household coal and firewood use or multidimensional poverty. Poisson models and scatterplots were used to further explore these relationships. The analyses revealed that these statistical associations were attributable to outlier values; for example, in the Northern Zone, Putre and Camarones had a high prevalence of residential coal and firewood use for household heating and cooking, as well as a high prevalence of multidimensional poverty, yet a low rate of adverse health events. Conversely, counties such as Punta Arenas, Natales, and Porvenir in the Southern Zone had moderate-to-high rates of health events and multidimensional poverty, but the prevalence of residential carbon and firewood use was low. When these outliers were removed from the analysis, the paradoxical correlations were no longer significant.

\section{CONCLUSIONS}

The analysis indicated a relationship between residential coal and firewood combustion and respiratory health events, including hospitalizations and deaths, in counties located in the southern zone of Chile; however, this relationship was not found in the other geographic zones of the country. In the northern zone, the prevalence of coal and firewood was low, likely due to hotter climatic conditions and therefore a lower demand for household heating. The population-level results obtained are consistent with studies of individual subjects which have shown causal relationships between burning biomass fuels, such as coal or firewood and respiratory problems. For example, polycyclic aromatic hydrocarbons (PAH) emissions from biomass combustion have been linked to the development of acute respiratory infections in children (Group OR 1.78; 95\% CI: 1.26-2.21) [28], chronic obstructive pulmonary disease in adults (Group OR 2.8; 95\% CI: 1.85-4.0), and chronic bronchitis (Group OR: 2.32; 95\% CI: 1.92-2.80) [29].

It should be noted that the types of fuels used were heterogeneous even in a given zone in this study. As shown in Figure 2, coal and firewood combustion were prevalent in the southern regions according to CASEN 2015 data, especially for household heating, while the far-southern regions - Magallanes and Antarctica - had a much lower prevalence for use of these fuels. Natural gas is subsidized in the southernmost regions, and as a result, nearly $100 \%$ of households in these areas use gas for all or most of their energy needs (Policy Paper 2). Furthermore, the heterogeneity of fuel use is due not only to price, but also to cultural values associated with the customs or idiosyncrasies of each community. Data from the 2015 National Energy Survey indicate than nearly $30 \%$ of households nationwide reported using firewood as their main source of energy [30].

This study was not able to establish an association between residential coal and firewood use and total or cardiovascular morbidity or mortality nationwide. The results derived from southern counties were consistent with previous literature; however, in northern counties, an inverse correlation was found between the county-level prevalence of firewood and coal uses for cooking and water heating, and total and cardiovascular mortality. This finding are not consistent with results observed at the individual level; for instance, in a cohort of nonsmoking Chinese women, there was a positive correlation between exposure to coal combustion for cooking and allcause mortality (HR: 1.12, 95\% CI: 1.05-1.21), cardiovascular mortality (HR: 1.18, 95\% CI: 1.02-1.37), ischemic cardiopathy (HR: 1.61, 95\% CI: 1.14-2.27), and myocardial infarct (HR: 1.80, 95\% CI: 1.16-2.79) [31]. Moreover, a systematic review of studies carried out in various parts of the world - South Asia, China, Turkey, Iran, and Central and South America - showed increased cardiovascular risk attributable to exposure to fossil fuel combustion [32]. Although the scope of this study did not extend to individual-level inferences, it is important to consider potential explanations for these discrepancies. In this study, the scarce variability of the indicator for multidimensional poverty at the county level and the presence of outliers induced this paradoxical correlation. This phenomenon became apparent with the scatterplots; it became clear that the presence of outliers had skewed the results, and when these anomalous values were removed, the associations were no longer significant. Moreover, there were other elements in each of these counties, such as diet, green spaces, and lifestyle factors, that may influence physical health. The analysis did not include a detailed study of these potential confounding factors. 
Other limitations of this study include the use of secondary data. The quality of mortality data available in the national Chilean database was very high; however, the use of hospitalization rate as an indicator of morbidity may induce a bias, given that patients are typically hospitalized only if symptoms are severe. Therefore, the figures used may under-represent respiratory morbidity. Second, while the prevalence of coal and firewood burning as a proxy for air pollution may be a representative indicator in some counties, this metric may not be as relevant where the main sources of air pollution are automobile emissions or industrial sources, such as foundries or thermoelectric plants, rather than not household fuel combustion. This source of error may explain the paradoxical correlations found in several counties, especially those located in the central and northern zones.

Although multidimensional poverty was not the main focus of this study, it is interesting to note that there was a positive correlation between this metric and total and respiratory mortality in only one of the three geographic zones studied, suggesting that socio-economic status is a strong determinant of individual-level health inequities only in the central zone. Furthermore, there was a positive correlation (0.68) between multidimensional poverty and the prevalence of coal and firewood combustion in southern zone counties, but this relationship was not observed in the other two zones. This finding suggests that geographic location should continue to be taken into account in studies on this topic. Although the definition of multidimensional poverty used in the CASEN survey included items on housing conditions and access to basic services, in the current study no significant relationship were found between poverty and the use of solid fuels, such as firewood and coal, either for the country as a whole or on the county level in the northern and central zones. Therefore, it would appear that the CASEN data do not demonstrate a direct correlation between multidimensional poverty and fossil fuel combustion, or the corresponding issues with air quality.

Strengths and significance of the study. This study characterized population-level usage of coal and firewood as residential fuel, as well as some of the health effects of these energy sources, highlighting the role of geographic region and local climate in determining the energy needs of the population. The analysis also tangentially described the relationship between multidimensional poverty and coal and firewood combustion for various household purposes, allowing for a county-level approximation of energy demands.

In recent years, the concept of energy poverty has been addressed by the Chilean government as well as governments and non-governmental organizations worldwide. This concept refers to situations in which segments of the population lack sufficient energy to cover basic household needs, taking into account the accessibility, quality, and equity of the energy sources available. This study analyzed secondary data in order to estimate county-level prevalence of residential coal and firewood combustion and to address issues related to equity, measured as the level of multidimensional poverty in a given county.

It has been shown that energy poverty has deleterious effects on the health of a population [33]. Research that elucidates the health effects of burning various types of solids fuels supports the design of public policies to effectively satisfy the nation's energy needs, promoting universal and equitable access to affordable and clean energy sources, without compromising the health and wellbeing of the population. Countries should use an evidence-based decision-making approach to develop energy policies that address these basic ethical issues, both to ensure equitable access to energy sources and to protect the environment in which the population lives. Issues such as social vulnerability and quality of life should be considered when designing and evaluating such policies, with the aim of strengthening the framework and infrastructure of strategic plans, taking into account issues associated with regional and cultural factors [34].

\section{Acknowledgment}

The authors acknowledged the Energy Poverty Network in Chile for motivating the discussion about energy poverty and health. The study did not require funding.

\section{REFERENCES}

1. United States Environmental Protection Agency. What Is Green Power? [Internet]. 2018 [cited 2018 Dec 26]. Available from: https://www.epa. gov/greenpower/what-green-power

2. United States Environmental Protection Agency. Energy and Environment. Learn about Energy and its Impact on the Environment. [Internet]. 2018 [cited 2018 Dec 26]. Available from: https://www.epa. gov/energy/learn-about-energy-and-its-impact-environment

3. Seow WJ, Downward GS, Wei H, Rothman N, Reiss B, Xu J, et al. Indoor concentrations of nitrogen dioxide and sulfur dioxide from burning solid fuels for cooking and heating in Yunnan Province, China. Indoor Air. 2016 Oct; 26(5): 776-83.

4. Zheng X, Ding H, Jiang L, Chen S, Zheng J, Qiu M, et al. Association between Air Pollutants and Asthma Emergency Room Visits and Hospital Admissions in Time Series Studies: A Systematic Review and Meta-Analysis. PLoS One. 2015; 10(9): e0138146.

5. Smith K, Organización de las Naciones Unidas para la Alimentación y la Agricultura. El uso doméstico de leña en los países en desarrollo y sus repercusiones en la salud [Internet]. 2006 [cited 2018 Dec 26]. Available from: http://www.fao.org/tempref/docrep/fao/009/a0789s/a0789s09.pdf

6. Fullerton DG, Bruce N, Gordon SB. Indoor air pollution from biomass fuel smoke is a major health concern in the developing world. Trans R Soc Trop Med Hyg. [Internet]. 2008 Sep; 102(9): 843-51. Available from: https://www.ncbi.nlm.nih.gov/pubmed/18639310

7. Rogalsky DK, Mendola P, Metts TA, Martin WJ 2nd. Estimating the number of low-income americans exposed to household air pollution from burning solid fuels. Environ Health Perspect. 2014 Aug; 122(8): 806-10.

8. Po JYT, FitzGerald JM, Carlsten C. Respiratory disease associated with solid biomass fuel exposure in rural women and children: systematic review and meta-analysis. Thorax. 2011 Mar; 66(3): 232-9.

9. World Health Organization. Burning opportunity: clean household energy for health, sustainable development, and wellbeing of women and children. [Internet]. 2016 [cited 2018 Dec 26]. Available from: https://www.who.int/airpollution/publications/burning-opportunities/ en/

10. Ministerio del Medio Ambiente. Gobierno de Chile. Informe del Estado del Medio Ambiente [Internet]. 2016 [cited 2018 Dec 26]. Available from: http://sinia.mma.gob.cl/wp-content/uploads/2017/08/IEMA2016.pdf

11. Gomez-Lobo A, Lima J, Hill C, Meneses M. Diagnóstico del Mercado de la leña en Chile. Informe Final preparado para la Comisión Nacional de Energía de Chile. Centro Micro Datos, Departamento de Economía, Universidad de Chile. [Internet]. 2006 [cited 2020 Apr 19]. Available from: http://metadatos.mma.gob.cl/sinia/articles-50791_informe_ final.pdf

12. Centro Desarrollo Tecnológico. Medición del consumo nacional de leña y otros combustibles sólidos derivados de la madera. Informe Final. 2015.

13. Lim SS, Vos T, Flaxman AD, Danaei G, Shibuya K, Adair-Rohani H, et al. A comparative risk assessment of burden of disease and injury attributable to 67 risk factors and risk factor clusters in 21 regions, 1990-2010: a systematic analysis for the Global Burden of Disease Study 2010. Lancet (London, England). 2012 Dec; 380(9859): 2224-60. 
14. Chow JC, Watson JG, Mauderly JL, Costa DL, Wyzga RE, Vedal S, et al. Health effects of fine particulate air pollution: lines that connect. J Air Waste Manag Assoc. 2006 Oct; 56(10): 1368-80.

15. Pope CA 3rd. Epidemiology of fine particulate air pollution and human health: biologic mechanisms and who's at risk? Environ Health Perspect. 2000 Aug; 108 Suppl: 713-23.

16. Laden F, Neas LM, Dockery DW, Schwartz J. Association of fine particulate matter from different sources with daily mortality in six U.S. cities. Environ Health Perspect. 2000 Oct; 108(10): 941-7.

17. Zhou J, Ito K, Lall R, Lippmann M, Thurston G. Time-series analysis of mortality effects of fine particulate matter components in Detroit and Seattle. Environ Health Perspect. 2011 Apr; 119(4): 461-6.

18. Barrios Casas S, Peña-Cortés F, Osses Bustingorry S. Efectos de la contaminación atmosférica por material particulado en las enfermedades respiratorias agudas en menores de 5 años. Vol. 10, Ciencia y enfermería. scielocl; 2004. p. 21-9.

19. Caceres D, Adonis M, Retamal C, Ancic P, Valencia M, Ramos X, et al. Indoor air pollution in a zone of extreme poverty of La Pintana, Santiago-Chile. Rev Med Chil. 2001 Jan; 129(1): 33-42.

20. Programa de las Naciones Unidas para el Desarrollo, Ministerio de Energía. Gobierno de Chile. Pobreza energética: Análisis de experiencias internacionales y aprendizajes para Chile [Internet]. 2018 [cited 2018 Dec 26]. Available from: http://www.cl.undp.org/ content/dam/chile/docs/medambiente/undp_cl_medioambiente_ pobrezaenergeticaexperienciainternacional_5_2_18.pdf

21. Ministerio de Energía. Gobierno de Chile. Energía 2050. Política energética de Chile [Internet]. 2015 [cited 2018 Dec 26]. Available from: http://www.minenergia.cl/archivos_bajar/LIBRO-ENERGIA2050-WEB.pdf

22. Sarricolea P, Herrera-Ossandon M, Meseguer-Ruiz Ó. Climatic regionalisation of continental Chile. J Maps [Internet]. $2017 \mathrm{Nov}$ 25 [cited 2020 Apr 19]; 13(2): 66-73. Available from: https://www. tandfonline.com/doi/full/10.1080/17445647.2016.1259592

23. Observatorio Social. Ministerio de Desarrollo Social. Encuesta Casen 2015 [Internet]. 2018 [cited 2018 Dec 26]. Available from: http://observatorio.ministeriodesarrollosocial.gob.cl/casenmultidimensional/casen/docs/CASEN_2015_Situacion_Pobreza.pdf
24. Ministerio de Salud. Gobierno de Chile. Departamento de Estadística e Información de Salud, DEIS [Internet]. [cited 2018 Dec 26]. Available from: http://www.deis.cl/

25. Instituto Nacional de Estadísticas. Chile. Demográficas y vitales. Proyecciones de población / Proyección base 2002 [Internet]. 2018 [cited 2018 Dec 26]. Available from: http://ine.cl/estadisticas/demograficasy-vitales

26. Fecht D, Fortunato L, Morley D, Hansell AL, Gulliver J. Associations between urban metrics and mortality rates in England. Environ Heal A Glob Access Sci Source [Internet]. 2016 Dec 8 [cited 2020 Apr 19]; 15(S1): S34. Available from: https://ehjournal.biomedcentral.com/ articles/10.1186/s12940-016-0106-3

27. Araya Sánchez M. Diagnóstico del Exceso de Mortalidad de la comuna de Independencia. Universidad de Chile; 2016.

28. Dherani M, Pope D, Mascarenhas M, Smith KR, Weber M, Bruce N. Indoor air pollution from unprocessed solid fuel use and pneumonia risk in children aged under five years: a systematic review and metaanalysis. Bull World Health Organ. 2008 May; 86(5): 390-398C.

29. Kurmi OP, Semple S, Simkhada P, Smith WCS, Ayres JG. COPD and chronic bronchitis risk of indoor air pollution from solid fuel: a systematic review and meta-analysis. Thorax. 2010 Mar; 65(3): 221-8.

30. Urquiza A, Amigo C, Billi M, Leal T. Pobreza Energetica en Chile: Análisis de fuentes secundarias disponibles de alcance nacional. 2017;

31. Kim C, Seow WJ, Shu X-O, Bassig BA, Rothman N, Chen BE, et al. Cooking Coal Use and All-Cause and Cause-Specific Mortality in a Prospective Cohort Study of Women in Shanghai, China. Environ Health Perspect. 2016 Sep; 124(9): 1384-9.

32. Fatmi Z, Coggon D. Coronary heart disease and household air pollution from use of solid fuel: a systematic review. Br Med Bull. 2016 Jun; 118(1): 91-109.

33. Thomson H, Snell C, Bouzarovski S. Health, Well-Being and Energy Poverty in Europe: A Comparative Study of 32 European Countries. Int J Environ Res Public Health. 2017 May; 14(6).

34. Rodríguez C. Aspectos bioéticos relacionados con la política energética de América Latina. Rev Colomb Bioética [Internet]. 2016; 11: 68-91. Available from: https://www.redalyc.org/html/1892/189246655005/ 
Supplement. Correlation matrix for all-natural causes mortality, respiratory and cardiovascular mortality, total and respiratory hospital admissions, multidimensional poverty, and firewood and coal use for cooking, household heating and water heating

\begin{tabular}{|c|c|c|c|c|c|}
\hline & & $\begin{array}{l}\text { Multidimensional } \\
\text { poverty }\end{array}$ & $\begin{array}{l}\text { Firewood/coal for } \\
\text { cooking }\end{array}$ & $\begin{array}{l}\text { Firewood/coal for } \\
\text { household heating }\end{array}$ & $\begin{array}{l}\text { Firewood/coal for water } \\
\text { heating }\end{array}$ \\
\hline Northern & All-natural causes mortality rate & -0.59 & -0.76 & -0.22 & -0.21 \\
\hline \multirow[t]{8}{*}{ counties } & Respiratory mortality rate & -0.37 & -0.24 & 0.10 & -0.29 \\
\hline & Cardiovascular mortality rate & -0.16 & -0.12 & 0.28 & -0.02 \\
\hline & Total hospital admissions & -0.31 & -0.11 & 0.13 & -0.25 \\
\hline & Respiratory hospital admissions & -0.15 & -0.09 & 0.17 & 0.02 \\
\hline & Multidimensional poverty & 1.00 & 0.81 & 0.22 & 0.58 \\
\hline & Firewood/coal for cooking & & 1.00 & 0.43 & 0.52 \\
\hline & Firewood/coal for household heating & & & 1.00 & 0.14 \\
\hline & Firewood/coal for water heating & & & & 1.00 \\
\hline Central & All-natural causes mortality rate & 0.43 & -0.03 & 0.01 & -0.19 \\
\hline \multirow[t]{8}{*}{ counties } & Respiratory mortality rate & 0.06 & 0.00 & 0.12 & -0.08 \\
\hline & Cardiovascular mortality rate & 0.24 & -0.05 & 0.00 & -0.23 \\
\hline & Total hospital admissions & -0.27 & 0.08 & -0.09 & -0.16 \\
\hline & Respiratory hospital admissions & -0.13 & 0.29 & 0.02 & -0.02 \\
\hline & Multidimensional poverty & 1.00 & 0.24 & 0.28 & 0.22 \\
\hline & Firewood/coal for cooking & & 1.00 & 0.78 & 0.67 \\
\hline & Firewood/coal for household heating & & & 1.00 & 0.58 \\
\hline & Firewood/coal for water heating & & & & 1.00 \\
\hline Southern & All-natural causes mortality rate & 0.20 & 0.14 & 0.01 & 0.11 \\
\hline \multirow[t]{8}{*}{ counties } & Respiratory mortality rate & 0.02 & 0.10 & 0.26 & 0.10 \\
\hline & Cardiovascular mortality rate & -0.05 & -0.07 & -0.07 & -0.01 \\
\hline & Total hospital admissions & 0.23 & 0.16 & 0.31 & -0.01 \\
\hline & Respiratory hospital admissions & 0.30 & 0.20 & 0.36 & 0.02 \\
\hline & Multidimensional poverty & 1.00 & 0.68 & 0.50 & 0.55 \\
\hline & Firewood/coal for cooking & & 1.00 & 0.67 & 0.89 \\
\hline & Firewood/coal for household heating & & & 1.00 & 0.53 \\
\hline & Firewood/coal for water heating & & & & 1.00 \\
\hline
\end{tabular}

